\title{
Studies on Domestic and Overseas in Research Progress of Agricultural Information Technologies
}

\author{
Ying $\mathrm{Yu}^{1}$, Cunjun $\mathrm{Li}^{1}$, Leigang Shi ${ }^{1}$, Heju Huai ${ }^{1}$, and Xiangyang Qin ${ }^{2, *}$ \\ ${ }^{1}$ Beijing Research Center for Information Technology in Agriculture, Beijng 100097, China \\ ${ }^{2}$ Beijing Academy of Agriculture and Forestry Sciences, Beijing 100097, China \\ \{yuy, licj, shilg, huaihj\} @nercita.org.cn, \\ qinxiangyang@baafs.net.cn
}

\begin{abstract}
This paper is a comparative study of domestic and overseas in the aspect of agricultural information technologies research progress. In domestic, it is short of independent development of core technology in precision operation integrated system. The key problem that needs to be resolved in agricultural information acquisition and analysis technology is how to improve the accuracy, the agricultural products information collection technology is still a blank. Lacking of shared and integrated simulation platform in agricultural digital model and virtual technology, and agricultural productivity prediction and early warning technology still needs to be improved. In the technology of agricultural intelligent decision, China is blank in the field of knowledge grid, knowledge sharing cannot be achieved. The high technical cost and the low operation reliability are the main problems in agricultural intelligent equipment. In modern agricultural mechanical equipment technology, China is lack of uniformed standards and regulations. There is a big gap between domestic and overseas in rapid detection technology and bio-mechanical composite technology.
\end{abstract}

Keywords: Agricultural information, technology, domestic, overseas.

\section{Introduction}

The modern advanced agricultural information technologies have been much interest in not just precision agriculture (PA), but also in areas where precision operation technology integrated system, agricultural information acquisition and analysis technology, agricultural digital model and virtual technology, agricultural intelligent decision technology, agricultural intelligent equipment technology, modern agricultural mechanical equipment. And these technologies were fast developed in the world-wide, especially in some developed countries.

China has occupied the first positions in the list of countries with the fastest growing 100 cities. The implications of such dramatic shifts for economic development, urbanization and energy consumption are immense [1]. However, China

\footnotetext{
* Corresponding author.
} 
as a large agricultural country, the application of information technology in agriculture area is at the starting stage, but has achieved great accomplishments. The aim of this paper is to comparative analysis on agricultural information key technologies of domestic and overseas that will promote the communication and development of the technologies in the world-wide.

Rapid socio-economic changes in some developing countries, including China, are creating new scopes for application of agricultural information technology. PA is conceptualized by a system approach to re-organize the total system of agriculture towards a low-input, high-efficiency, and sustainable agriculture. Many researchers applied the precision technology to manage farmland product system and agricultural product traceability system etc. FH Wang [2] pointed that there were many soft and hardware, such as 3S, farmland information acquisition system, and intelligent field variable-rate operation system etc. were studied and applied in China. Besides, four key technological components, i.e., field information collection, field information management, variable-rate decision-making, and variable-rate technologies were analyzed and evaluated; the impacts of precision agriculture on farm input, crop yield and quality were summarized; the barriers for development and adoption of precision agriculture were also pointed out by CJ Zhao etc. [3, 4]. NQ Zhang etc. [5] have provided the impact of precision agriculture technologies on farm profitability and environment, worldwide applications and adoption trend of precision agriculture technologies, and potentials of the technologies in modernizing the agriculture in China.

Related research has overwhelmingly showed that rural residents have an extensive range of information needs, with agricultural technological information, market information, income generation information and policy information being the most needed; and that they rely very much on interpersonal relationships for acquiring both general information and information for agriculture production [6]. Therefore, the agricultural information acquisition and analysis technology is urgent demand in rural area. Lake [7] reported that studies of Internet adoption in the general U.S. population had produced estimates of 60 to 100 million households using the Internet. Within the U.S. farm population, Internet adoption in 1999 was estimated at $43 \%$ for U.S. farms with sales over $\$ 100,000$ [8]. Computer adoption on U.S. farms has been studied by many researchers. Business characteristics such as experience with other technology, the use of farm records services, the use of consultants, the size of the farm business, the complexity of the farm business, the level of farm income, the type of commodities produced by the farm, and the number of employees have been hypothesized to affect PC adoption [9, 10, 11]. These studies have taken the perspective that the computer is an integral tool for turning farm data into information upon which management can act. In other words, the computer is a key element of the managerial information system (MIS) on most farms [12].

Worldwide, farmers are increasingly purchasing and using on-farm computers to provide decision support information and assist in meeting their tax and other reporting commitments. While, having purchased, the farmers clearly believe the investment is justified, there is some before and after data to support this conclusion. $[13,14]$ Nuthall[15] pointed out that, on average, the profit has tended to increase 
after purchasing a computer. However, the wide variations and involvement of many factors make categorical conclusions difficult. It leaves open the question whether computer technology makes it easier for good managers to make decisions that in the past were of a similar quality but took longer to obtain, perhaps with subconscious observation and intuition, in contrast to the computer based decision systems actually creating valuable new information.

In agriculture production, we have a well-established range of instruments for measuring variables such as mass, volume, temperature, relative humidity, gas and fluid flow. All are capable of working reliably in the agricultural environment, with sufficient accuracy for most purposes. Usually they are based on a sensor in direct contact with the solid, liquid or gas concerned [16, 17].

Drabenstott [18] has identified five challenges that will be critical in shaping the rural economic outlook in the USA, but they applied to many other settings as well: tapping digital technology, encouraging entrepreneurs, leveraging the new agriculture, improving human capital, and sustaining the rural environment. Three of the five are connected rather directly to the digital economy and the use of information and communication technologies (ICTs): digital technology, entrepreneurship, and human capital. The new agriculture also exploits new technologies and assembles them (GPS, databases and geographic information systems) into precision agriculture to optimize agricultural inputs to specific locations, perhaps with little involvement of farmers' themselves [19].

Fountas etc. [20] described the development of a system based model to characterize farmers' decision-making process in information-intensive practices, and its evaluation in the context of precision agriculture. A participative methodology was developed in which farm managers decomposed their process of decision-making into brief decision statements along with associated information requirements. A knowledge-based intelligent e-commerce system for selling agricultural products was found out by W Wen [21]. The KIES system not only provided agricultural products sales, financial analysis and sales forecasting, but also provided feasible solutions or actions based on the results of rule-based reasoning.

Use of computers and sensors for real-time decisions in cropping systems is increasing rapidly. Yet, the value of technology can be best realized when integrated with agronomic knowledge, resulting in a seamless process of assessment, interpretation, and targeted operation [22]. Henten [23] etc. indicated a procedure and the results of an optimal design of the kinematic structure of a manipulator to be used for autonomous cucumber harvesting in greenhouses.

Research activities concerning automatic guidance of agricultural vehicles have led to various solutions. Sensors, including mechanical ones, global navigation satellite systems (GNSS), machine vision, laser triangulation, ultrasonic and geomagnetic, generate position, attitude and direction-of-movement information to supply control algorithms. In America, a conceptual framework of an agricultural vehicle guidance automation system includes navigation sensors, navigation planner, vehicle motion models, and steering controllers [24]. In Europe, Keicher [25] etc. indicated that it was depending on who is funding the project, the systems range from a PC, with a frame grabber or a GNSS receiver used to guide an implement along a predefined 
path with speeds up to $3 \mathrm{~m} / \mathrm{s}$, to a multiprocessor bifocal road recognition system for autonomous cars driving on motorways with a speed of $130 \mathrm{~km} / \mathrm{h}$.

All the development of agricultural information technologies in the world-wide is as to improve agriculture production efficiency and farmer income, reduce the damage to environment, and promote the sustainable development of agriculture.

\section{The Key Technologies}

\subsection{Precision Operation Technology Integrated System}

In China, it is immature of the precision control technology, and the precision operation guidance system is not very reliable. The theoretical research on zoning management is not enough, and its system application cost is very high. Generally, the precision operation integrated system is lack of core and key technologies.

Table 1. Precision operation technology integrated system

\begin{tabular}{|c|c|}
\hline Key technology & Comparison \\
\hline \multirow[t]{2}{*}{$\begin{array}{l}\text { Precision soil } \\
\text { preparation and seeding }\end{array}$} & $\begin{array}{l}\text { Overseas: the application of precision seeding operation has been } \\
\text { widespread }\end{array}$ \\
\hline & Domestic: laser has been applied in soil preparation \\
\hline \multirow[t]{2}{*}{$\begin{array}{l}\text { Precision } \\
\text { technology }\end{array}$} & 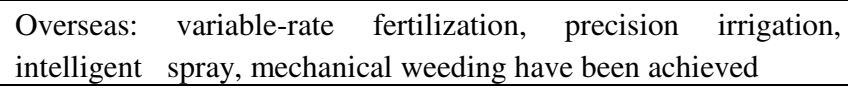 \\
\hline & $\begin{array}{l}\text { Domestic: variable-rate fertilization of single fertilizer has been } \\
\text { accomplished }\end{array}$ \\
\hline \multirow{2}{*}{$\begin{array}{l}\text { Precision } \\
\text { management } \\
\text { prescription } \\
\text { technology }\end{array}$} & $\begin{array}{l}\text { Overseas: the application of zoning management and prescription } \\
\text { map technology has been popular }\end{array}$ \\
\hline & $\begin{array}{l}\text { Domestic: variable-rate fertilization on single plot has been used } \\
\text { in the demonstration stage }\end{array}$ \\
\hline \multirow[t]{2}{*}{$\begin{array}{l}\text { Precision } \\
\text { system }\end{array}$} & $\begin{array}{l}\text { Overseas: auto and assistant guidance system has been used on } \\
\text { farmland operation }\end{array}$ \\
\hline & $\begin{array}{l}\text { Domestic: assistant operation guidance has been used on regional } \\
\text { demonstration }\end{array}$ \\
\hline \multirow[t]{2}{*}{$\begin{array}{l}\text { Precision } \\
\text { system }\end{array}$} & $\begin{array}{l}\text { Overseas: the technology has been applied in field, orchard, } \\
\text { greenhouse, animal husbandry, fishery and forestry }\end{array}$ \\
\hline & Domestic: only the main field crops have been demonstrated \\
\hline
\end{tabular}

Gao Liangzhi [26] accounted that agriculture system is a complex system which composed of agricultural biology, agricultural environment, agricultural technology and agricultural economy - the four subsystems, with a certain internal relations. Luo Xiwen [27] introduced the precision agriculture technology system from the thought of technology, supporting technology, operation process and application examples. Zhao Chunjiang [3] analyzed and discussed the technology of precision agriculture system from the four key technological components of precision agriculture (information acquisition, information analysis, decision making and decision 
implementation). Cao Hongxin et al. [28] discussed the digital cultivation framework and technical system.

Precision agriculture cannot work without the construction of agricultural information infrastructure, and the basic of infrastructure construction is the network connection device. According to the statistics of USDA in 2009, digital subscriber line (DSL) was the most common method of accessing the Internet. The second is Satellite and wireless, and cable is the third method. In China, the infrastructure building in Beijing had certain scale, and the network coverage in rural counties and the rate of network into villages almost reached $100 \%$ [29].

\subsection{Agricultural Information Acquisition and Analysis Technology}

In the international, sensor is developing rapidly but in China, it is still in the primary stage. The cost of sensor research in agriculture is high and its accuracy is much low, that is the same difficulty as agricultural information acquisition technology. China had no research inthe key technology of agricultural products information collection. Lack of sharing platform,model design and low monitoring accuracy which are the significant problems in remote sensing.

Table 2. Agricultural information acquisition and analysis technology

\begin{tabular}{l|l}
\hline \multicolumn{1}{c|}{ Key technology } & \multicolumn{1}{c}{ Comparison } \\
\hline $\begin{array}{l}\text { Growth information } \\
\text { acquisition technology }\end{array}$ & $\begin{array}{l}\text { Overseas: crop growth, physical and chemical properties, disease } \\
\text { pest and weed have been detected intelligently }\end{array}$ \\
\cline { 2 - 2 } & $\begin{array}{l}\text { Domestic: sensor detection of plant growth has been } \\
\text { accomplished }\end{array}$ \\
\hline Soil information & $\begin{array}{l}\text { Overseas: sensor system online measurement of the main soil } \\
\text { physical and chemical properties has been achieved }\end{array}$ \\
\cline { 2 - 2 } acquisition technology & $\begin{array}{l}\text { Domestic: sensor system achieved the measurement of soil } \\
\text { moisture and hardness }\end{array}$ \\
\hline \multirow{2}{*}{$\begin{array}{l}\text { ingricultural products } \\
\text { technology }\end{array}$} & $\begin{array}{l}\text { Overseas: nanotechnology and biochip technology etc advanced } \\
\text { technologies have been widely used }\end{array}$ \\
\cline { 2 - 2 } $\begin{array}{l}\text { Remote sensing } \\
\text { information acquisition } \\
\text { technology }\end{array}$ & $\begin{array}{l}\text { Overseas: remote sensing have been applied in determination of } \\
\text { soil physical and chemical properties and crop growth, and } \\
\text { fertilization recommendation on internet }\end{array}$ \\
\cline { 2 - 2 } & $\begin{array}{l}\text { Domestic: remote sensing has been used in crop classification, } \\
\text { farmland area estimation, growing of large-range detection }\end{array}$ \\
\hline
\end{tabular}

The key information technologies in agricultural inforamtion acquisition, it mainly included of some aspects as below: the rapid detection technology, auto identification technology, the system and platform of agricultural products, network technology and database technology.[30] 
In university of California, Davis, a new test scanner was developed which used in testing the wine whether deterioration without opening the packaging. The development of the scanner referred to the magnetic resonance imaging (MRI) technology which is widely used in the field of medicine; it can detect acetic acid in wine. In Germany, there was a light, rapid and effective PEN2 electronic nose system, it was used in inspecting and testing gaseous matter and steamy, now all the scent of meat, fruit, yogurt, milk, alcohol and coffee etc could be tested by it. [31].

Beijing CapitalBio Corporation and Beijing Entry-Exit Inspection and Quarantine Bureau cooperated to develop 'Protein Chip Veterinary drug residues in protein microarray platform', multiple samples in a variety of veterinary drug residues could be detect on the same chip [32]. Changchun Jilin University Instrument Co., Ltd developed a serial of measuring instruments, one of them is 'Pesticide Residues in Food Supplies fast detector', it can be applied to flour, rice, soybeans, green beans surface-site rapid detection of pesticide residues [33]. Chinese Military Academy of Medical Sciences used indicator paper and the light reflection sensors to develop equipment: 'portable multi-function devices for food safety rapid testing'. It was the first time to blend the following technologies together, such as electro-optical technology, sensor technology, microelectronics, micro-mechanical technology, computer technology and food safety testing technology, the testing covered all kinds of food daily, each sample test only 15 seconds to 30 minutes [34].

Near infrared spectroscopy in the soil inspection has a good application, to determine soil moisture, organic matter, total nitrogen and available nitrogen, organic carbon and total carbon [35]. Laser-induced breakdown spectroscopy (LIBS) has emerged in the past ten years as a promising technique for analysis and measure [36]. A Laser induced breakdown spectroscopy (LIBS) system used for detecting heavy metals in polluted soil was established. Samples containing various heavy metals such as $\mathrm{Cd}, \mathrm{Cu}, \mathrm{Pb}, \mathrm{Cr}, \mathrm{Zn}, \mathrm{Ni}$ and soil sample were analyzed by this system, and main spectral lines of heavy metals and main elements were recognized [37].

Shen Guanglei etc designed and developed a beef quality and safety traceability system via internet technology. The system adopted JSP to design the ObjectOriented dynamic pages and adopted the MySQL to design the database. The B/S (Browser/Server) structure was used to put the management system on the internet, which implemented the management of beef traceability system via internet and made the beef traceability system be more networking and popularizing [38].

Based on analyzing agricultural products traceability and investigating the producing enterprises of agricultural products, agricultural products archive management system (FPAMS) with B/S (Browser/Server) structure was founded by using database technology [39].

\subsection{Agricultural Digital Model and Virtual Technology}

In the digital agriculture area, there is seldom application in simulation object and dynamic model in China. The R\&D of platform and model is lack of sharing and integration. Time, space productivity prediction and early warning need to be strengthened. 
Table 3. Agricultural digital model and virtual technology

\begin{tabular}{|c|c|}
\hline Key technology & Comparison \\
\hline \multirow{2}{*}{$\begin{array}{l}\text { Digital modeling } \\
\text { technology of bio- } \\
\text { environmental system }\end{array}$} & $\begin{array}{l}\text { Overseas: the prediction of plant and animal growth, output and } \\
\text { quality has been achieved }\end{array}$ \\
\hline & $\begin{array}{l}\text { Domestic: simulation of the growth and output of main crops } \\
\text { has been accomplished }\end{array}$ \\
\hline \multirow{2}{*}{$\begin{array}{lr}\text { Agricultural } & \text { biologic } \\
\text { form } & \text { virtual } \\
\text { representation } & \\
\text { technology } & \\
\end{array}$} & $\begin{array}{l}\text { Overseas: the morphological change process of main agriculture } \\
\text { and forestry plant has been dynamic displayed }\end{array}$ \\
\hline & $\begin{array}{l}\text { Domestic: static virtual of the main agriculture and forestry } \\
\text { plant on growth period has been accomplished }\end{array}$ \\
\hline \multirow[t]{2}{*}{$\begin{array}{l}\text { Digital visual bio- } \\
\text { mimetic platform }\end{array}$} & $\begin{array}{l}\text { Overseas: function and structure coupled crop growth simulation } \\
\text { system and components have been formed }\end{array}$ \\
\hline & $\begin{array}{l}\text { Domestic: crop growth and environment simulation system is } \\
\text { still in build }\end{array}$ \\
\hline \multirow{2}{*}{$\begin{array}{l}\text { Agricultural biologic } \\
\text { system virtual design } \\
\text { technology }\end{array}$} & $\begin{array}{l}\text { Overseas: agronomy system design and environmental effect } \\
\text { assessment have been achieved based on scenario simulation }\end{array}$ \\
\hline & $\begin{array}{l}\text { Domestic: part of the virtual design and regulation has been } \\
\text { used based on simulated evaluation }\end{array}$ \\
\hline \multirow{2}{*}{$\begin{array}{l}\text { Agricultural productivity } \\
\text { prediction and early } \\
\text { warning technology }\end{array}$} & $\begin{array}{l}\text { Overseas: model has been applied on region productivity } \\
\text { prediction and management under climate change }\end{array}$ \\
\hline & $\begin{array}{l}\text { Domestic: productivity prediction and analysis under site level } \\
\text { has been achieved }\end{array}$ \\
\hline
\end{tabular}

The digital resource of 'National Cultural Information Resources Sharing Project' has reached 105.28TB, an accumulative total of 890 million people who got services. 'E-home' is the primary public information service place in rural areas, its number had reached 824; China has more than 250 rural digital cinemas, nearly 40,000 digital cinema projection equipment in rural areas [40].

The potential for rural areas to benefit from telecommunications technology is a persistent question [41]. Rural America is digital: rural communities and people are connected to the Internet. The definitive 2000 report, Falling through the Net [42], and its 2002 counterpart, A Nation Online [43] found that rural households, which historically trailed those in central cities and urban areas, have shown significant gains in Internet access.

\subsection{Agricultural Intelligent Decision Technology}

The low utilized information and non-shared knowledge is the problem of agricultural information fusion and knowledge discovery technology in domestic. It is still a blank of the application of knowledge grid technology in the field of agriculture. In the decision support technology, the self-learning ability needs to be improved. 
Table 4. Agricultural intelligent decision technology

\begin{tabular}{l|l}
\hline \multicolumn{1}{c|}{ Key technology } & \multicolumn{1}{c}{ Comparison } \\
\hline $\begin{array}{l}\text { Information fusion } \\
\text { technology }\end{array}$ & $\begin{array}{l}\text { Overseas: multi-information fusion technology has been } \\
\text { achieved }\end{array}$ \\
\cline { 2 - 3 } $\begin{array}{l}\text { Knowledge discovery } \\
\text { technology }\end{array}$ & Overseas: massive knowledge base building has been achieved \\
\cline { 2 - 3 } & $\begin{array}{l}\text { Domestic: the structure of knowledge base is single and not } \\
\text { uniform }\end{array}$ \\
\hline \multirow{2}{*}{$\begin{array}{l}\text { Knowledge grid } \\
\text { technology }\end{array}$} & $\begin{array}{l}\text { Overseas: knowledge grid calculation technology has been } \\
\text { achieved }\end{array}$ \\
\cline { 2 - 3 } $\begin{array}{l}\text { Decision } \\
\text { technology }\end{array}$ & $\begin{array}{l}\text { Oomestic: the knowledge grid technology is just starting } \\
\text { achieved }\end{array}$ \\
\cline { 2 - 3 } & Domestic: the application of expert system is very well \\
\hline
\end{tabular}

At the moment, the AGROVOC thesaurus is mapped to the following recourses: EuroVoc [44], NALT [45], GEMET [46], LCSH [47], STW-Thesaurus for Economics [48], and RAMEAU [49]. With the launch of the AGROVOC linked open data [50], the stage is set for organizations around the world to start publishing their agriculture knowledge models by linking them to AGROVOC, as well as utilizing AGROVOC for resource management. Here in MIMOS, we are publishing four knowledge models in agriculture. The first being a generic crop ontology, followed by ontology each for tomato, corn and chili. Dickson Lukose briefly described the evolution of the LOD, the emerging world-wide semantic web (WWSW), and explore the scalability and performance features of the service oriented architecture that forms the foundation of the semantic technology platform developed at MIMOS Bhd., for addressing the challenges posed by the intelligent future internet[51].

\subsection{Agricultural Intelligent Equipment Technology}

In China, the cost of network building and maintenance is very high of intelligent monitoring technology, especially the cost of sensor which applied in detection. It is weakness of the study foundation of the model intelligent control technology. Single species and low reliability are the problem of intelligent robot.

At present, the farm computer equipment is mainly used to conduct online transactions. In 2009, 81 percent of U.S. farms with sales and government payments had access to a computer, 79 percent owned or leased a computer, 69 percent were using a computer for their farm business, and 76 percent had Internet access [52]. In Japan, about $34 \%$ households had PC, of which $12.2 \%$ had access to the internet [53]. 
Table 5. Agricultural intelligent equipment technology

\begin{tabular}{|c|c|}
\hline Key technology & Comparison \\
\hline \multirow[t]{2}{*}{$\begin{array}{l}\text { Intelligent monitoring } \\
\text { technology }\end{array}$} & $\begin{array}{l}\text { Overseas: the multi-parameter detection simultaneously and } \\
\text { wireless network have been achieved }\end{array}$ \\
\hline & $\begin{array}{l}\text { Domestic: single point monitoring and wireless transmission has } \\
\text { been accomplished }\end{array}$ \\
\hline \multirow[t]{2}{*}{$\begin{array}{l}\text { Intelligent } \\
\text { technology }\end{array}$} & $\begin{array}{l}\text { Overseas: linkage control based on growth and environment has } \\
\text { been achieved }\end{array}$ \\
\hline & $\begin{array}{l}\text { Domestic: control technology has not been combined with } \\
\text { growing }\end{array}$ \\
\hline \multirow{2}{*}{$\begin{array}{l}\text { Intelligent detection } \\
\text { technology }\end{array}$} & Overseas: the detection is intelligent and the operation is easy \\
\hline & $\begin{array}{l}\text { Domestic: intelligent environment monitoring hasn't been } \\
\text { accomplished }\end{array}$ \\
\hline \multirow{2}{*}{$\begin{array}{l}\text { Intelligent } \\
\text { technology }\end{array}$} & Overseas: intelligent robot has been developed in multi-domain \\
\hline & $\begin{array}{l}\text { Domestic: intelligent robot is still in developing and no mature } \\
\text { products }\end{array}$ \\
\hline
\end{tabular}

Gloya [54] found that in the USA, the producers were not sure as to how the information technology can best be used in their farm to create value. Furthermore, in India Raju [55] concluded that organizational linkages and networking capacities are to be strengthened for 'digital unity' to provide multiple opportunities to the agriculture communities to exploit local resources for their self-development. In New Zealand rural areas, farmers are increasingly purchasing and using on-farm computers to provide decision support information and assist in meeting their tax and other contracts management. While the farmers purchase on Internet, they clearly believe the investment is justified, although there is not enough data to support this conclusion [56].

For China, the issue of agricultural communication development has been conventionally examined under labels such as universal service, digital, divide, broadband deployment, and e-government, which generally fall into two seemingly distinct categories - access and applications. In China, these concepts are currently incorporated into a single program, if not a single term-'Village Informatization Program' ('VIP') [57, 58].

\subsection{Modern Agricultural Mechanical Equipment}

It is short of uniformed standards and regulations of large-scale agricultural operations control system in domestic. The intelligent equipment control level is lower than developed countries and lack of common platform. The rapid detection technology of agricultural products processing equipment still needs to be improved. There is no research in the area of bio-mechanical composite technology. 
Table 6. Modern Agricultural mechanical equipment

\begin{tabular}{l|l}
\hline \multicolumn{1}{c|}{ Key technology } & \multicolumn{1}{c}{ Comparison } \\
\hline $\begin{array}{l}\text { Large tractor operation } \\
\text { control system }\end{array}$ & $\begin{array}{l}\text { Overseas: onboard communication, bus control, condition } \\
\text { monitoring and self-walking function have been achieved }\end{array}$ \\
\cline { 2 - 2 } $\begin{array}{l}\text { Large } \\
\text { equipment }\end{array}$ & $\begin{array}{l}\text { Domestic: traditional integrated circuit and electric relay control } \\
\text { has been used }\end{array}$ \\
\hline \multirow{2}{*}{$\begin{array}{l}\text { Hills } \\
\text { equipment }\end{array}$} & $\begin{array}{l}\text { Overseas: intelligent cotton picker, grain combine harvester has } \\
\text { been developed }\end{array}$ \\
\cline { 2 - 2 } $\begin{array}{l}\text { Agricultural products } \\
\text { processing equipment }\end{array}$ & $\begin{array}{l}\text { Domestic: there is medium-sized combine harvester, no } \\
\text { intelligent cotton picker }\end{array}$ \\
\cline { 2 - 2 } & $\begin{array}{l}\text { Overseas: hills operation has been mechanization } \\
\text { have been accomplished }\end{array}$ \\
\cline { 2 - 2 } Bio-mechanical & Domestic: fruit mechanical classification has been achieved \\
\hline composite technology & $\begin{array}{l}\text { Overseas: human-machine coordination and object tracking has } \\
\text { been achieved }\end{array}$ \\
\cline { 2 - 2 } & Domestic: no research in this area \\
\hline
\end{tabular}

Holland, Italy, France, UK, Spain, USA, Canada, Israel, Turkey, Japan, Korea, Australia and other countries started earlier in agricultural technology research facility, which developed fast and in the highest level of the world currently[59,60]. $\mathrm{Xu}$ Fang et al. summarized the survey and development of agricultural mechanical equipment in protected agriculture. It included machinery for seeding, transplanting, automatic engrafting, cultivating, harvesting and transporter for vegetable production. Flower-product ion machines and agricultural robots were also introduced. Some problems about the technical development of agricultural machinery in protected agriculture in the future are discussed [61].

\section{Conclusions}

The key agricultural information technologies comparison of domestic and overseas shows that, although the beginning of China is late the development is very fast. But in some key technologies, there is still a large gap with the developed countries. The main problem of Chinese agricultural information technology is that the basic research and deep development is not enough, lacking of independent core technology, reliability and accuracy is low. The development of high accuracy sensor is the main technical difficulty, and the high cost is also a problem. In digital agriculture, it is short of deeply theoretical research and technology development, and the agricultural prediction and early warning ability still needs to be improved. There is no uniformed standards and regulations in mechanical equipment development, the low information utilization is a serious factor to restrict knowledge sharing and hinder intelligent decision support system development. It is still a blank in some technology 
research fields in China, such as agricultural information collection technology, knowledge grid technology and bio-mechanical composite technology etc.

China as a large developing country, there is no advantage to compare with developed countries in resource and environment etc. Currently, China is confronted with huge competitive pressure on the quality of agricultural products and benefit of agricultural production. There is much practical value and strategic significance in researching and developing agricultural information technology, to reduce agricultural production costs, improve the output and quality of agricultural products.

Acknowledgment. Funds for this research was provided by the construction of integrated information "three dimensional rural" service platform in National Modern Agricultural City for Science and Technology Projects (D121100003212003).

\section{References}

1. Mondal, P., Basu, M.: Adoption of precision agriculture technologies in India and in some developing countries: Scope, present status and strategies. Progress in Natural Science 19, 659-666 (2009)

2. Maohua, W.: Thinking through the experiment, demonstration and development research on precision agriculture. Journal of Agricultural Science and Technology 5(1), 7-12 (2003)

3. Zhao, C., Xue, X., Wang, X., Chen, L., Pan, Y., Meng, Z.: Advance and prospects of precision agriculture technology system. Transactions of the Chinese Society of Agricultural Engineering 19(4), 7-12 (2003)

4. Zhao, C.: Progress of agricultural information technology. International Academic Publishers. International Academic Publisher (2000)

5. Zhang, N., Wang, M., Wang, N.: Precision agriculture-a worldwide overview. Computers and Electronics in Agriculture 36, 113-132 (2002)

6. Yao, Z., Yu, L.: Information for social and economic participation: A review of related research on the information needs and acquisition of rural Chinese. The International Information \& Library Review 41(2), 63-70 (2009)

7. Lake, D.: Spotlight: how big is the U.S. net population? The Industry Standard (November 29), http: / / www. thestandard.com/metrics/display/

0,2149, 1071, $00 . \mathrm{html}$ (accessed January 6, 2000)

8. National Agricultural Statistics Service (NASS), Agricultural Statistics Board, U. S. Department of Agriculture, Farm Computer Usage and Ownership (1999)

9. Lewis, T.: Evolution of farm management information systems. Computers and Electronics in Agriculture 19, 233-248 (1998)

10. Amponsah, W.A.: Computer adoption and use of information services by North Carolina commercial farmers. Journal of Agricultural and Applied Economics 27, 565-576 (1995)

11. Baker, G.A.: Computer adoption and use by New Mexico nonfarm agribusinesses. American Journal of Agricultural Economics 74, 737-744 (1992)

12. Gloya, B.A., Akridge, J.T.: Computer and internet adoption on large U.S. farms. International Food and Agribusiness Management Review 3, 323-338 (2000)

13. Lazarus, W.R., Strecter, D., Jofré-Girando, E.: Management information system: impact on dairy farm profitability. North Central Journal of Agricultural Economics 12, 267-277 (1990) 
14. Verstegen, J.A.A.M., Huirne, R.U.M., Dijkhuizen, A.A., King, R.P.: Quantifying economic benefits of sow-herd management information systems using panel data. American Journal of Agricultural Economics 77, 387-396 (1995)

15. Nuthall, P.L.: Case studies of the interactions between farm profitability and the use of a farm computer. Computers and Electronics in Agriculture 42, 19-30 (2004)

16. Cox, S.: Measurement and Control in Agriculture. Blackwell Science, Oxford (1997)

17. Cox, S.: Information technology: the global key to precision agriculture and sustainability. Computers and Electronics in Agriculture 36, 93-111 (2002)

18. Mark, D.: New policies for a new rural America. International Regional Science Review 24, 3-15 (2001)

19. Tsouvalis, J., Seymour, S., Watkins, C.: Exploring knowledge cultures: precision farming, yield mapping, and the expert—farmer interface. Environment and Planning A 32, 909924 (2000)

20. Fountas, S., Wulfsohn, D., Blackmore, B.S., Jacobsen, H.L., Pedersen, S.M.: A model of decision-making and information flows for information-intensive agriculture. Agricultural Systems 87, 192-210 (2006)

21. Wen, W.: A knowledge-based intelligent electronic commerce system for selling agricultural products. Computers and Electronics in Agriculture 57, 33-46 (2007)

22. Newell, R.K.: Emerging technologies for real-time and integrated agriculture decisions. Computers and Electronics in Agriculture 61(1), 1-3 (2008)

23. Van Henten, E.J., Van't Slot, D.A., Hol, C.W.J., Van Willigenburg, L.G.: Optimal manipulator design for a cucumber harvesting robot. Computers and Electronics in Agriculture 65(2), 247-257 (2009)

24. Reid, J.F., Zhang, Q., Noguchi, N., Dickson, M.: Agricultural automatic guidance research in North America. Computers and Electronics in Agriculture 25, 155-167 (2000)

25. Keicher, R., Seufert, H.: Automatic guidance for agricultural vehicles in Europe. Computers and Electronics in Agriculture 25, 169-194 (2000)

26. Gao, L.: Fundamentals of Agricultural Systems. Jiangsu science and Technology Press, Nanjing (1993)

27. Luo, X., Zhang, T., Hong, T.: Technical System and Application of Precision Agriculture. Transactions of the Chinese Society of Agricultural Machinery 32(2), 103-106 (2001)

28. Cao, H., Zhang, C., Jin, Z., et al.: The discussion of the framework and technical system of digital cultivation. Tillage and Cultivation (3), 4-7, 40 (2005)

29. Yu, Y., Qin, X., Zhang, L.: Development status of rural informatization in Beijing, China. International Journal of Agriculture \& Biological Engineering 4(4), 59-65 (2011)

30. Yu, Y., Li, J., Qin, X.: The Information Key Technologies for Quality \& Safety Monitor and Management of Agricultural Products. Advanced Materials Research 634-638, 40044010 (2013)

31. Wang, X., Cao, Y., Ma, J., Huang, F., Yu, A.: New advances in fast detection techniques for quality and security control of farm produce. Modern Scientific Instruments 1, 121-123 (2006)

32. Wu, L., Dong, J.: Simultaneous detection of a variety of veterinary drug residues, 'protein chip for detection of veterinary drug residues platform'. Jiangxi Feed 3, 41 (2005)

33. Feng, G., Wang, X., Xie, F., Yu, A.: The in situ detection of residual pesticide in rice, flour, fruit and vegetable. Modern Scientific Instruments 1, 86-88 (2005)

34. Wang, X., Wu, Z.: Food safety on-site rapid detection equipment comes out. Family \& Traditional Chinese Medicine 12, 13 (2005) 
35. Chen, P., Liu, L., Wang, J., Shen, T., Lu, A., Zhao, C.: Real-time analysis of soil $\mathrm{N}$ and $\mathrm{P}$ with near infrared diffuse reflectance spectroscopy. Spectroscopy and Spectral Analysis 28, 295-298 (2008)

36. Wang, J., Zhang, N., Hou, K., Li, H.: Application of LIBS technology to the rapid measure of heavy metal contamination in soils. Progress in Chemistry 20, 1165-1171 (2008)

37. Yu, L., Zhao, H., Ma, X., Liu, Y., Zhang, M., Liao, Y.: Research of LIBS method for detection of heavy metals in polluted soil. Laser Journal 5, 66-67 (2008)

38. Shen, G., Zan, L., Duan, J., Wang, L., Zheng, T.: Implementation of beef quality and safety traceability system via internet. Transactions of the Chinese Society of Agricultural Engineering 23, 170-173 (2007)

39. Yang, X., Qian, J., Sun, C., Liu, X., Han, X.: Implement of farm product archives management system based on traceability system. Chinese Agricultural Science Bulletin 22, 441 (2006)

40. Yu, Y., Qin, X.: Study on Rural Cultural and Entertainment Informatization Status in China. In: 2011 International Conference on Future Information Technology, vol. 13, pp. 402-406 (2011)

41. Malecki, E.J.: Digital Development in Rural Areas: Potentials and Pitfalls. Journal of Rural Studies 19, 201-214 (2003)

42. NTIA. National Telecommunications and Information Administration. Falling Through the Net: Toward Digital Inclusion (2000), Information on,

http://www.ntia.doc.gov/ntiahome/fttn00/contents00.html

43. NTIA and ESA. National Telecommunications and Information Administration and Economics and Statistics Administration. A Nation Online: How Americans Are Expanding Their Use of the Internet. NTIA, Washington, DC (2002)

44. Euro Voc. Euro Voc: multilingual thesaurus of the European Union (2011), http: / / eurovoc. europa. eu/drupal/

45. NALT. Agriculture thesaurus and glossary, national agriculture library, United States department of agriculture, United States of America (2011),

http://agclass.nal.usda.gov/agt.shtml

46. GEMET. General multilingual environmental thesaurus, European topic center on catalogue of data sources, European environmental agency (2011),

http: / / www. eionet. europa. eu/gemet

47. LCSH 2011, Library of Congress Classification Outline, The library of Congress, United States of America. (2011), http: / /www. loc.gov/catdir/cpso/ lcco/STW

48. STW Thesaurus for economics, Leibniz information center for economics, http: / / zbw.eu/stw/versions/latest/about

49. RAMEAU. Répertoire d'autorité-matière encyclopédique et alphabétique unifié, National Library of France (2011), http: / / rameau . bnf . fr/

50. ALOD. AGROVOC linked open data. Food and Agriculture Organization of the United Nations (FAO) (2011), http: //aims.fao.org/website/Linked-Open-Data/sub

51. Lukose, D.: World-Wide Semantic Web of Agriculture Knowledge. Journal of Integrative Agriculture 11(5), 769-774 (2012)

52. Farm computer usage and ownership. Washington: National Agricultural Statistics Service, Agricultural Statistics Board, U.S. Department of Agriculture (2009)

53. Zhao, Y.: The characteristics of agriculture informatization in developed countries. Chinese Rural Economy (7), 74-78 (2002)

54. Brent, A., Gloya, J.T.: Computer and internet adoption on large U. International Food and Agribusiness Management Review (3), 323-338 (2000) 
55. Raju, K.A.: A case for harnessing information technology for rural development. The International Information \& Library Review 36(3), 233-240 (2004)

56. Nuthall, P.L.: Case studies of the interactions between farm profitability and the use of a farm computer. Computers and Electronics in Agriculture (42), 19-30 (2004)

57. Xia, J.: Linking ICTs to rural development: China's rural information policy. Government Information Quarterly 27(2), 187-195 (2010)

58. Xia, J., Luingjie: Bridging the digital divide for rural communities: The Case of China. Telecommunications Policy 32, 686-696 (2008)

59. Von Elsner, B., Briassoulis, D., Waaijenberd, D., et al.: Review of structural and functional characterist ics of greenhouses in European Union countries, Part I: design requirements. Part II: typical design. Journal of Agricultural Engineer Research 75(1-16), $111-126(2000)$

60. Wang, M.: The development of industrialized agriculture and Engineering Science and technology innovation. Publishing house, Beijing (2000)

61. Xu, F., Zhang, L., Ji, S., Wan, Y.: Mechanical equipment in protected agriculture and its technical development. Journal of Zhejiang University of Technology 29(2), 136-141 (2001) 